\title{
THE ROLE OF THE STOCK MARKET IN THE PROVISION OF ISLAMIC DEVELOPMENT FINANCE: EVIDENCE FROM SUDAN
}

\begin{abstract}
This paper assesses the impact of stock exchange funding in the shari'ya compliant Islamic economy of Sudan. Evidence suggests that while Islamic financial instruments have considerable potential in facilitating development finance through their emphasis on partnership this is better achieved by the banking system rather than the Khartoum stock exchange. A case study of the Sudan Telecommunications company shows that larger firms able to cross-list elsewhere are likely to choose regional markets in preference to their domestic one thus benefiting from lower costs of equity. However, governance preferences are likely to favour block shareholders following the Islamic finance partnership concept.
\end{abstract}

Keywords: Sudan, Islamic Finance, Emerging Financial Markets 


\section{THE ROLE OF THE STOCK MARKET IN THE PROVISION OF ISLAMIC DEVELOPMENT FINANCE: EVIDENCE FROM SUDAN}

\section{INTRODUCTION}

Islamic finance has only achieved prominence both in practice and in the literature relatively recently (Mannan, 2003) with the first Islamic banks established in Kuwait and Egypt during the 1960s and 1970's and the Islamic Development Bank in 1975 (Rowey et al., 2006). While there is a considerable literature on the principles of Islamic economics, that concerning Islamic finance largely focuses on either contrasting the structure and design of financial products with those in the West (see Kamali (2007) or Abdoulli (1991)) or on the Islamic banking system (Aggarwal and Yousef (2000); Lewis and Algaoud (2001)). Further, any literature that does exist on the role and regulation of stock markets within an Islamic economy focuses largely on the normative prescriptions of Islamic finance as a discipline (see El-Din and El-Din (2002) and Naughton and Naughton (2000) for an extended discussion).

This study explores the role of the stock exchange as a source of finance and the implications this has for development finance, using a case study of the Sudanese stock market. Of particular interest is the provision of funds to support regional expansion for the Sudan Telecommunications Company. Thus, this paper addresses two research questions. The first examines the ability of the Khartoum stock exchange, an Islamic shari'ya compliant stock market, to provide cost effective finance within a developing context. The second relates to the financing options available to the Sudan Telecommunications company.

The paper is structured as follows. Section 2 presents the theoretical aspects of Islamic economics and finance as a sub-discipline before introducing the principle factors governing regulation and product design in this context. Section 3 reviews the prominent Middle East and North African (MENA) regional stock exchanges and the institutions defining the Khartoum stock market (KSE). Section 4 studies the role of the KSE in the financing strategy of the Sudan Telecommunications Company, an example of a prominent multinational enterprise in a developing Islamic economy. Section 5 provides a review of the impediments to an effective Islamic compliant 
stock exchange in a developing country drawing on data from Sudan. The final section concludes and suggests policy implications.

\section{2}

\section{THEORETICAL BACKGROUND TO ISLAMIC FINANCIAL MARKETS}

The relatively recent emergence of Islamic economic institutions in the MENA region is largely due to the reassertion of Islamic values following the post-colonial period during which Western and Marxist principles dominated (Kuran, 1995) as countries aligned themselves to the capitalist or socialist orders of the Cold War (Chapra, 1992).

Islam represents a system of beliefs based on the interpretation of passages from the Qu'ran and various Had'ith and Sunnah, which are short texts concerning customs of the Muslim community and relating experiences of the prophet Mohammed (Pryor, 2007). These form the basis of Shari'ya law, which permeates all areas of the wider Islamic system, including economics, finance, law, politics and government as integral component parts, and which have common values of Islamic social justice (Asutey, 2007). However, as Pryor (2007) notes, Muslim policy makers are faced with considerable dilemmas over omissions from canonical texts, as well as differing translations and contradictory interpretation of these doctrinal sources by the various schools of Muslim jurisprudence (Pryor (2007); El-Din and El-Din (2002)).

But while the political economy aspects of the Islamic system encompasses all component of a social system the central belief of Islamic economics is that individuals are merely the trustees of wealth and capital owned by God (Chapra (1992) and Asutey (2007)). As Islamic economics is only one part of the wider system where individuals have common values and adhere to Shari'ya principles the ethical behavioural norms of Islam are fully integrated with economic motives. Thus, ethical actions of the individual within this system are not voluntary but rather defined as part of the revealed knowledge derived from the teachings of the Qu'ran. Shari'ya law is thus the binding set of principles that govern the economic, social, ethical and religious aspects of Islamic society (Iqbal, 1997). Therefore, the Islamic order can be viewed as providing "the economic system with its basis and objectives on one hand, and with its axioms and principles on the other" (Kahf, 1989). Consequently 
the normative prescriptions of Islamic economics are operationalised through axioms, or fundamental principles, which provide a basis for rationalising and verifying knowledge (Asutey, 2007).

\subsection{Islamic Finance}

The Islamic financial system is founded and regulated on the same shari'ya principles as the overall economy and society (Iqbal, 1997). These dictate the nature of contracts traded, the design of institutions to support the market and the regulation of participants' behaviour. Individuals within an Islamic financial system will be subject to behavioural norms, which give rise to very different assumptions to those that form the basis of regulation in western markets. Consequently, it is also necessary to reconsider standard western valuation models as these may not be applicable in an Islamic context. This section reviews the optimal regulation of the Islamic stock exchange, describes the most commonly used products and then addresses alternative valuation models.

\section{(i) Islamic Regulation}

The literature concerning Islamic regulation is largely normative and prescriptive (Metwally (1984); El-Din and El-Din (2002)). This is largely a symptom of the lack of practical application given there are only a handful of fully shari'ya compliant financial systems worldwide (Pryor, 2007). Pakistan, Iran and Sudan are the only countries with fully compliant banking systems while only Iran and Sudan have fully compliant stock markets (Pryor, 2007). Organised securities markets are largely required for risk diversification and to facilitate the redistribution of wealth and investment from investors to development projects (Metwally, 1984).

The products traded on an Islamic stock exchange must conform to the concept of partnership where business risks are borne equally by all partners. Because of the prohibition of interest (riba) the Islamic stock market can be defined as a share market with transactions undertaken solely in ownership contracts (Naughton and Naughton, 2000). However, there is a considerable contrast between the nature of the share markets in western and Islamic economic systems. Firstly the Islamic financial market has a number of distinct products that are based on the principles of partnership between entrepreneur and provider of capital and these will be described in greater detail in the 
following section. Secondly the common share, or equity, differs between Western and Islamic definitions in principal due to the way the contract addresses asymmetric information between the capital issuer and provider. The Islamic system views the equity contract, that is ordinary shares with voting rights, as a form of Mudarabah, where a contract is initiated between at least two partners with one providing all the capital and the other the management of the business. However, where in the Western system the risk of asymmetric information is mitigated by extensive legal contracting between parties in an Islamic adherence to Islamic social values is reinforced by shari'ya compliance. Thus, the prohibition of speculation (gharrar) and any form of gambling (qimar), including the manipulation of share prices for personal gain, together with the practices acting to informationally disadvantage any party (jahalah) are part of the shari'ya code regulating markets. These practices reflected common shared Islamic ethical values (Mannan (1993); Naughton and Naughton (2000)).

The normative prescriptions placed on the institutional design result in the Islamic stock market being very different from that in the west. For example, the prohibition of practices such as selective information disclosure (jahalah) and speculation or gambling has considerable inference both on the institutional design of the stock market and the rules on disclosure, accounting and auditing, which in turn affect the informational content of prices (Naughton and Naughton, 2000). The western rules on disclosure of information and ownership, which act to disadvantage some investors to the benefit of others (jahalah) is not allowed and disclosure in Islamic markets leads to strong-form efficiency (Fama, 1970) where share prices reflect all available information in both public and private domains (Naughton and Naughton (2000); El-Din and El-Din (2002)). While this serves to outlaw practices such as insider trading between "informed" and "uninformed" investors (Rock, 1986) its effectiveness in practice is controversial (El-Din and El-Din, 2002). The concept of strong form efficiency in practice is not supported by the literature as firms often seek to retain at least some confidential information regarding their operations ${ }^{1}$. Furthermore, the listings on many markets, especially in developing countries, are made up largely of smaller firms. These would face considerable difficulty in meeting the fixed costs associated with frequent information disclosure requirements and cause the stock market to be a less attractive venue for raising finance compared to

\footnotetext{
${ }^{1}$ Onour (2002) found little evidence of weak, semi-strong, or strong-form efficiency using Khartoum Stock Exchange data.
} 
the banking system. Although El-Din (1996) proposes government assistance for smaller companies in meeting financial obligations arising from costly information disclosures this is questionable as markets would then only operate under a system of state subsidies and not be independent.

Another fundamental difference is the institutional concepts of information and allocative efficiency. The western model seeks to use the presence of arbitrage traders, who profit from price differences between the same security traded in different locations thereby acting to close pricing and information gaps in the market. Financial markets arbitrageurs often use short sales, that is borrow stock in order to execute a trading strategy and make a profit. Often their actions are speculative and used to exploit differences in price, thus increasing information efficiencies and reducing overall transactions costs. However, in an Islamic market short-selling is considered to be unacceptable (Naughton and Naughton, 2000) as is gambling and speculation (El-Din and El-Din, 2002). As the securities traded represent partnerships that imply an equal burden of risk and reward on both capital issuers and investors, the notions of information disclosure and efficiency must be considered in the context of a close cooperation by both parties. Concerns regarding asymmetric information are thus mitigated through the common adherence to shari'ya principles of all parties and therefore regulation relating to information disclosure the concept of information efficiency occurs by the prescriptive behavioural norms in shari’ya compliance.

Islamic financial systems commonly follow the self-regulatory model, particularly in Islamic banking systems (El-Din and El-Din, 2002). While El-Din and El-Din (2002) extend the validity of the self-regulatory model to Islamic stock markets there is also evidence of such a practice in Sudan (KSE annual report, 2004). Thus, in Khartoum, a commercially trained and independent shari'ya council acts alongside the stock exchange in advising on acceptable financial instruments and activities on the exchange and also endorse regulations (KSE annual report, 2004).

\section{(ii) Islamic financial products}

A critical feature of the Islamic financial system is that the proliferation of financial products and legal definitions of the firm, or partnership, are subject to validation by the various schools of Islamic jurisprudence (Mannan, 1993). While these are generally in agreement over common products such as 
mudarabah, musharaka, murabaha and ijara, as well as the less common mugawla and salam, there is considerable consternation over more recently developed products that bear a strong resemblance to western debt instruments. The prohibition of interest (riba), which is the major distinguishing features of Islamic finance, is controversial because of differing interpretations by the various schools of Islamic jurisprudence of the translation from the Qu'ran of the definition of usury (Noorzoy, 1982). Kuran (1995) also notes that the original prohibition of riba was due to the ancient "pre-Islamic Arabian practice of doubling the debt of a borrower unable to make restitution on schedule, including both the principal and accumulated interest". As this tended to push defaulters into enslavement it was the source of real tension and its ban was effectively a form of bankruptcy protection, reflecting the concept of social justice in Islam (Kuran, 1995). However, despite the ban on riba, or any products offering a fixed schedule of repayments, few countries have been able to prevent the use of debt-based instruments entirely (Pryor, 2007) because of the global nature of international financial (Aggarwal and Yousef, 2000) and the dominance of western financial principles in that system (Asad, 2008).

Central to Islamic financial product design is partnership and risk-sharing, which is commonly referred to as the profit-and-loss-sharing (PLS) paradigm (Presley and Sessions (1994); Aggarwal and Yousef (2000)). The exact division of responsibilities, and the levels of risk and reward allocated to each partner, is defined in the contract. This contract is enforced by the common ethical standards and social values within the shari'ya system, which ensures mutual compliance by all parties in the transaction.

The mudarabah contract is a partnership between the entrepreneur (mudarib) and at least one investor (rabb al-mal) (Aggarwal and Yousef, 2000) where the latter provides the sole source of capital. This is considered by many schools of Islamic jurisprudence to be the equivalent of common equity in western financial markets (Mannan, 1993). However, the difference arises because the Mudarabah contract implies a closer partnership than the more distant legally defined link between principal (investor) and agent (manager) in western finance. In the event of a loss associated with a Mudarabah contract, the investor earns no return and equally the entrepreneur receives no compensation for effort. If the project is successful then the gains are split between the parties according to the pre-transaction negotiated conditions of the contract. This is closer to limited liability 
partnerships common to western markets than a share instrument and has the further distinction of being restricted or unrestricted depending on the nature of pre-agreed restrictions on the use of funds by the entrepreneur (Aggarwal and Yousef, 2000). One consequence of the emphasis on partnership and risk sharing in mudarabah contracts and Islamic commercial jurisprudence is that the modern Middle Eastern business environment is dominated by small and family-owned firms while larger companies are either foreign Multinational Enterprises (MNEs), foreign joint ventures, or privatised state owned enterprises (Kuran, 2004). However, Badr El-Din (2003) notes there is a general perception in Sudan that mudarabah contracts are risky and consequently there is some reluctance to enter this type of partnership unless there is considerable confidence and existing trust between potential partners. This suggests that larger block shareholders dominate the Sudanese share market in order to mitigate concerns over contract risk.

In contrast, the musharaka contract involves a partnership where both partners, that is, entrepreneur and investor jointly provide the capital and manage the venture (Aggarwal and Yousef, 2000). Losses are in proportion to the individual capital contributions of the two parties while profits are negotiated freely (Aggarwal and Yousef, 2000). These contracts are more akin to a traditional equity stake with rights of control (Aggarwal and Yousef, 2000) and have been proposed as the optimal contract in developing the fledgling Islamic venture capital and private equity markets where a degree of capital provision together with some influence and control over incumbent management is necessary (Al-Suwailem (1998) and Khan and BenDjilali (2003)). Government shihama certificates, a variant of the musharaka contract, were introduced by the Bank of Sudan in 2001 through KSE auctions as a source of short term financing (KSE Annual report, 2004).

An additional contract, Murabaha, involves the resale of working capital or means of production after adding a specified profit margin, for which the minimum margin is determined by the central bank (Badr El-Din, 2003). Commonly, the entrepreneur makes an application to the bank or investment partner to finance the purchase of raw materials for production. Invoices for the materials accompany the application and the bank then buys the materials before reselling them back to the entrepreneur at their purchase price plus an agreed margin that includes administrative costs incurred and a profit margin for the bank (Badr El-Din, 2003). The more complicated structure of these 
instruments and the greater need for more active involvement of the investor means that these are better administered by banks than stock markets. This explains their dominance in the provision of microcredit by the banking sector rather than the stock exchange (Badr El-Din, 2003). The shari'ya compliant Islamic financial system does confer considerable benefits in the financing of smaller scale industry by these principles of social justice. This also acts as a protection against bankruptcy, which is important in smaller, riskier ventures, and suggests an emphasis on development by partnership rather than imposing the need for collateral and creditworthiness that is common in western financial systems. However, the major constraints to this type of financing are the selection of an appropriate guarantee for murabaha that is suitable for small, often poorly capitalised, entrepreneurs and the costs of surveillance and monitoring of projects following funding (Badr El-Din, 2003). These extremely high monitoring costs have caused all the major banks in Sudan to locate branches in industrially developed areas (Badr El-Din, 2003), which has caused development to be highly regionally concentrated.

Ijara, or lease, finance has undergone considerable recent growth and development. This is arranged by the banking sector and is a partnership where the bank as the investor buys and then leases out equipment required by the entrepreneur for a pre-agreed rent. The equipment remains an asset of the bank, which will recover both the capital cost plus a profit margin paid by entrepreneur (Rowey et al., 2006). Ijara contracts are typically used in the financing arrangements of large firms for high value industrial equipment such as aircraft, as with Sudan Airways and Emirates Airlines (Al Zawya, 2009). However, ijara contracts are similar to hire-purchase agreements in western markets and there are concerns over the fixed schedule of payments that suggest debt-type instrument, which are obviously prohibited (Aggarwal and Yousef, 2000).

Two less common contracts are Mugawla and Salam. These are commonly negotiated through the banking system. Mugawla financing involves a contract between the party undertaking a work-related function and the provider of capital or materials for the project. The price of the work under contract and the terms of payment must be specified at the outset, and payment may be made in advance, after completing the work, or in instalments as the work progresses. Salam financing is common in the agricultural sector where a contract is made between the supplier of inputs and the 
financial institution acting on behalf of the ultimate buyer. The key objective of this contract is to fix a price for the delivery of goods at a fixed future date (Mannan, 1993).

(iii) Valuation models in Islamic finance

Share valuation in an Islamic financial system involves revisiting the foundational principles of valuation theory in the absence of interest and with an emphasis on equity partnership. Consequently, the cost of capital in Islamic finance is expressed as an expected rate of profit, which is used to provide a discount rate for cash flows to calculate a Net Present Value (NPV) for the firm (Siddiqui, 2005). However, the expected rate of profit is itself a complex issue given the divergent views over the concept of the time value of money between Islamic and western finance (Obaidullah, 2006). The notion of profit and loss sharing and partnership inherent in Islamic contracts requires that an element of risk is borne by all partners and thus the portfolio investment models of Markowitz (1959) is largely acceptable in Islamic finance (Obaidullah, 2006). However, the concept of a risk free asset is not (Siddiqui, 2005) and this effectively rules out standard valuation models such as the capital asset pricing model, although more recently the development of a sovereign sukuk (Islamic bond) market has caused a resurgence of interest in the use of the expected rate of profits on sukuks as a proxy for risk free rates (Obaidullah, 2006).

While there is evidence that Sudanese firms use a number of different valuation techniques, such as Internal Rate of Return (IRR) and Payback Period (PB) (Eljelly and Abuldris, 2001), the use of dividend capitalization models (see for example Gordon and Shapiro (1956)) provides an alternative by overcoming the unresolved issues concerning risk-free rates of interest or yield and the lack of suitable benchmarks in conventional valuation models. Since Islamic finance provides for dividend payments, or the distribution of profits, associated with equity ownership (Mannan, 1993) valuation models using dividends are a viable alternative. The dividend capitalization method is outlined below,

$$
k_{s}=\frac{D_{t+1}}{P_{t}}+g
$$


where $k_{s}$ is cost of equity capital, $D_{t+1}$ is the next year's (estimated or forecasted) dividend, $P_{t}$ is the current stock price and $g$ is the long run expected dividend growth rate. While there is considerable debate in the literature regarding the calculation of the growth rate the most common formula is,

$$
g=(1-\rho) R o E
$$

where $(1-\rho)$ is the proportion of the retained earnings and $R o E$ the balance sheet item return on equity.

\subsection{Implications for corporate governance}

The differences in the institutional structure and products traded in the shari'ya compliant Islamic financial system and that in the west extend to the managerial governance of firms. Relationships between entrepreneurs (agents) and investors (principals) are heavily influenced by the concepts of partnership and mutual risk sharing in the Islamic system and the agency problems raised in the west are not overtly discussed. Rather, in an Islamic context the concept of corporate stewardship is through amana (trust) and umma (solidarity amongst Muslims), which reflects shared values "that Consequently, corporate culture in an Islamic organisation should be one in which Islamic values are reflected in all facets of group and individual behaviour and thus a collective morality is established to reinforce behavioural norms that define the approach to corporate governance and stewardship prescriptions. There is some empirical evidence (see Presley and Sessions (1994)) of improved surveillance, monitoring and compensation arising from the use of mudurabah contracts compared to western debt-based financing. However, the longer term partnership nature of mudurabah contracts supports the presence of large block-shareholders as opposed to smaller shareholders who are likely to be more interest in short-term gains rather than longer term, lower-return yet socially beneficial projects (Mannan, 1993). This further differentiates the incentive compatibility and organisational efficiency in the Islamic partnership system compared to the western system where short-term, profitmaximising shareholders exert pressure on managers. Consequently, corporate governance in an Islamic context favours a single tier board structure comprised of major block shareholders acting in a supervisory context over incumbent managers and the subsequent agency costs. 


\subsection{Characteristics of regional MENA markets}

The structure and regulation of securities markets across the MENA region tends to reflect the colonial legacy in terms of the legal systems and ranges of financial products. While many regional markets do have segments dedicated to Islamic products these are traded alongside western instruments, including debt, in countries such as Turkey, Egypt and Saudi Arabia (Aggarwal and Yousef, 2000). Table 1 shows that a lack of trading activity, indicated by turnover ratios of less than $10 \%$, is a major concern across the region. This is despite the considerable size of individual markets, for example, the Saudi Arabian Tadawul stock exchange has a market capitalization of US\$157,306.44m, which is over $43 \%$ of the total MENA markets. In contrast the North African exchanges together account for just under $12 \%$ of capitalization and the Sudanese exchange a mere $0.21 \%$. However, although while the little activity there is in MENA exchange is concentrated in Saudi Arabia and Kuwait, there is a more even distribution of market capitalization to GDP. This indicates the relative importance of the role the stock market in the economy. Four exchanges, Kuwait, Doha (Qatar), Amman (Jordan) and Bahrain, have market capitalization to GDP ratios greater than $100 \%$. The low levels of activity, small size, and relatively low levels of importance indicate that the banking sector plays a more active role in the provision of finance in the MENA region.

\section{Table 1}

\subsection{The Khartoum Stock Exchange (KSE)}

The Khartoum stock exchange (KSE) was established in 1994, helped by the Common Market for Eastern and Southern Africa (CoMESA) $)^{2}$. The market is fully Islamic shari'ya compliant with regulation following the self-regulatory model administered by both the central bank, Bank of Sudan, and the Shari'ya council (KSE website, 2007). Trading is conducted manually by continuous auction from Saturday to Thursday for one hour from 10-00am to 11-00am with buy and sell orders relayed to

\footnotetext{
${ }^{2}$ Member states are: Burundi, Comoros, Democratic Republic of Congo, Djibouti, Egypt, Eritrea, Ethiopia, Kenya, Libya, Madagascar, Malawi, Mauritius, Rwanda, Seychelles, Sudan, Swaziland, Uganda, Zambia and Zimbabwe
} 
floor-based representatives of registered brokers. The over-the-counter (OTC) market trades outside exchange trading hours and between licensed brokerage companies.

Table 2 shows the exchange has grown considerably since inception from 34 listed firms in 1995 to 51 in 2006 . This growth is matched by similar increases in activity, such the number of traded shares and market capitalisation. The OTC market is administered by the KSE legal affairs department and involves inter-family and inheritance transactions. These are complex due to the complicated nature of Islamic law involved in terminating a mudarabah partnership agreement following the death of one of the partners. The increases in the OTC market can be attributed to an increasing understanding and popularity amongst the domestic population for the stock exchange and its products. This has led to substantial increases in the ratio of market capitalization of OTC market to that of the secondary market. However, the increases in the traded value are more modest, beginning from US\$ $3.50 \mathrm{~m}$ in 1995 , rising to a peak of US\$ $178.04 \mathrm{~m}$ in 2004 and then falling to a final value of US\$ $51.46 \mathrm{~m}$ in 2006 . The ratios of market capitalization to GDP and market capitalization to money plus quasi-money are very low again suggesting that the KSE has a small role in economy and the banking sector dominates.

\section{Table 2}

The KSE has undergone significant innovation and in 1999 the secondary market was divided into an organized and parallel market. The less stringent disclosure requirements allow the parallel market to play a more active role in the development financing of smaller firms. Additional formal markets also exist for exchange traded funds (sukuks) (KSE Annual Report, 2004). The KSE has also benefitted from introduction of government shihama (a form of musharaka) certificates in 2001, which increased domestic awareness of exchange based investment products (KSE Annual Report, 2004). This caused substantial increases in traded volume and value as well as in OTC trading volumes.

The KSE has a small and highly concentrated local brokerage industry, shown in Table 3. A single company, the Financial Investment Bank, accounts for over $85 \%$ of total capitalisation. This was established with assistance from the government to facilitate the listing of the Sudan Telecommunications Company (Sudatel), which was part of an IMF recommended privatization. The 
brokerage industry is required by regulation to be located around Khartoum (KSE website, 2007), suggesting limited access by potential investors from across the country.

\section{Table 3}

Table 4 shows that the KSE equity market is highly skewed with only two firms, Sudatel and Sudanese Free Zones \& Markets, accounting for over $87 \%$ of the market capitalization. Sudatel alone dominates the KSE with over $62 \%$ of the market capitalization and over $83 \%$ of traded value. Further evidence of Sudatel's dominant position in the small market can be seen in Figure 1, which contrasts the growth of the Arab Monetary Fund (AMF) market index and the price index of Sudatel. It also shows annual trading volumes with a common base date of second quarter 2004.

The highly skewed nature of the KSE reflects the wider business environment in Sudan, which is comprised of many small family-owned and managed firms and a few large former state owned enterprises (Tignor, 1987). The tiny funds (sukuk) market is similar to the secondary market as both are totally dominated by the Second Sudatel Dollar Fund, which accounts for over 93\% of traded value in the funds segment that is itself a mere $0.62 \%$ of the overall KSE traded value. In contrast to the equity market the shihama market (a form of government musharaka contract) collectively accounts for $25.40 \%$ of the capitalization of the KSE and has a more even distribution of traded value between listed instruments.

\section{Tables 4 and 5}

\section{Figure 1}

Table 5 indicates that the ownership of listed firms is dominated by a small number of blockshareholders who have large equity stakes. The presence of these large block-shareholders is also confirmed by the generally very low free float percentages, that is, the proportion of shares freely available for the public. These block-shareholders support the domestic perception of mudarabah (equity) instruments as highly risky (Badr El-Din, 2003). Equally, there is a fear of loss of control in smaller family-owned firms and of expropriation by investors, particularly because of the lack of protection from the regulatory authority despite shari'ya compliance (Badr El-Din, 2003). Finally, the 
presence of block-shareholders fits the perception that in Islamic finance itself emphasis is placed on longer term partnerships (Naughton and Naughton, 2000).

There is also evidence of sovereign involvement in the equity market, either from direct ownership or indirectly through a variety of ministries and regional development agencies. As with the pattern of corporate ownership, the sovereign ownership that exists is dominated by Sudan and Saudi Arabia with the latter the only other country to have significant involvement in the market.

\subsection{Competition from the banking sector for provision of funds}

Relationship-based bank finance is the dominant source of business funding is responsible for industrial growth and economic development in Sudan and recently has recently channelled the revenues from windfall gains from oil production in the south. Table 6 shows an increase in from US\$20 million in 1998 to US\$4,860 million in 2006. Murabaha contracts are the most common form of finance, accounting for over 39\% of funding, while musharaka contracts can account for between $20 \%$ and $30 \%$. Mudarabah and salam contractual arrangements are considerably less common, and each accounts for up to $6 \%$ of banking sector funding. Finally, other more specialised forms of contractual arrangements (including ijara and mugawla contracts) together account for the remaining $12-20 \%$. Financing by murabaha contracts had the biggest increase in absolute terms between 1998 and 2006, although the relative proportions provided by each contract type remained relatively constant. The limited range of contract that can easily be traded on a stock exchange, together with considerable monitoring and enforcement costs, indicate that the banking system is better placed to deal with these issues.

\section{Table 8}

The demand for stock exchange products is very limited with an almost exclusive focus on the few comparatively wealthy industrialised areas such as Khartoum and Port Sudan. Extreme poverty is prevalent with over 20 million out of a total population of 34 million people living on less than 1US\$ per day in 2002 (Rural Poverty, 2008). The affects of over 20 years of conflict and the loss of over 1.5 million lives in outlying regions, plus one of the highest illiteracy rates has limited the potential 
demand for stock exchange products in favour of the banking sector and micro-credit initiatives. ${ }^{3}$ There are serious concerns regarding the application of basic auditing and accounting techniques (Ali, 2007) amongst the majority of the 285 registered firms in the Sudanese formal economy and the under-developed stock exchange institutions and limited geographic location means that the banking sector has little competition.

\section{THE EQUITY FINANCING OPTIONS FOR LARGER KSE LISTED FIRMS}

Large international firms seeking to compete in regional product markets face significant constraints on industrial expansion due to their inability to source cost effective finance. While this is a common issue facing any firms engaging in international production it is especially acute for firms from developing countries where financial markets are underdeveloped and costs of capital, or expected rates of profit, are very high. While the Khartoum stock exchange has three firms that are cross listed, only one, the Sudan Telecommunications Company (Sudatel) has a primary listing on the domestic exchange with cross listings on regional markets due to the need to fund further expansion in the highly competitive Maghreb telecommunications markets.

\subsection{The benefits of cross listing for firms}

The immediate benefits for KSE listed firms that cross list on other regional and international exchanges is that they can overcome the segmentation that is a barrier to accessible and cost effective finance. Segmentation in Sudan is a function of the shari'ya compliant market and the level of development. The first panel in Table 7 shows the regional cross listings of Sudatel between Bahrain and Abu Dhabi and reveals that the Abu Dhabi listing is almost double that of Khartoum. Similarly, both the turnover ratio and the traded value are considerably greater. These figures indicate that the secondary listing on the Abu Dhabi exchange is more frequently traded, is more liquid, and has provided Sudatel with a more cost effective source of finance. The Bahrain listing has lower market capitalization, approximately $10 \%$ of the Khartoum level, and with no traded value and a turnover ratio of zero. This listing is most likely motivated by the need to attract high net worth individuals

\footnotetext{
${ }^{3}$ Literacy rates were under 50\% in 11 out of 16 provinces in 2003 (UN Sudan Millennium Goals, 2004)
} 
from the Arabian Gulf emirate interested in a longer term Islamic compliant partnership. Estimates of the cost of equity are in the second panel of Table 7. These show a clear reduction in the Abu Dhabi listing compared to Khartoum, justifying the secondary listing.

\section{Table 7}

\subsection{The role of cross listings in attracting foreign investors}

The comparative ability of each of the two major listings of Sudatel in Khartoum and Abu Dhabi to attract foreign investors is examined by an application of mean-variance portfolio theory (for a detailed discussion of techniques see Harvey (1994)). These techniques are motivated through a combination of a lack of alternative methods in assessing investor options given the need for shari'ya compliance. Descriptive statistics and correlations for the Khartoum and Abu Dhabi listings of Sudatel and a range of benchmark equity indices from major regional financial markets are in Table 8 , namely: Saudi Arabia, Oman, Egypt, Bahrain, Kenya, Morocco and the Morgan Stanley Capital International index (MSCI). ${ }^{4}$ These data suggest that the mean-variance characteristics are poor in contrast to the regional benchmarks. Both stocks have low mean returns and very high standard deviations. However the correlations in the second panel of the table show that in Abu Dhabi there are mostly negative correlations with other regional benchmarks but positive in Khartoum suggesting the former offers regional portfolio managers a better opportunity to diversify risk.

\section{Table 8}

The comparative benefits to investors arising from including either of the two listings in regional portfolios is then examined using minimum variance portfolios that avoid unresolved issues between Islamic and western finance concerning utility maximisation. Five portfolios were constructed. The first two are centred on the Khartoum and Abu Dhabi listings plus the regional benchmarks. The last three focus on the Khartoum listing plus first Morocco and Egypt, then Egypt and Kenya, and finally Saudi Arabia and Oman.

\footnotetext{
${ }^{4}$ The MSCI market capitalisation weighted index is composed of companies representing the market structure of 22 developed market countries in North America, Europe, and the Asia/Pacific Region.
} 
The first panel in Table 9 provides further support for the dual listing in Abu Dhabi with improved mean return and standard deviation when included in a portfolio of regional assets compared with the Khartoum listing. The risk-return ratio, a modified version of the Sharpe ratio, shows the benefits to investors from including the Abu Dhabi (1.5289) asset compared to that in Khartoum (1.3437). The diversification benefits attributable to the Khartoum listing are in the second panel of Table 9. The combination of the Khartoum asset alongside the Saudi Arabian and Omani benchmark indices gives the lowest portfolio mean and standard deviation. Further evidence of the benefits to Saudi Arabian and Omani investors from including the Khartoum asset is shown from the risk-return ratios. This ratio for the portfolio with Saudi Arabia and Oman is higher (0.8999) than for either of the other two combinations, that is, Egypt and Kenya (0.7694) and Morocco and Egypt (0.8042). These results explain the presence of Saudi Arabian and Arabian Gulf investors in the Sudanese equity market as seen earlier in Table 5 .

\section{Table 9}

The evidence suggests that due to the segmentation of the KSE cross listing on more liquid regional exchanges larger firms engaged in highly competitive international production do have other options. However, the need for more cost effective finance must be balanced by the requirement to be shari'ya complaint. Consequently, firms adhering to the concept of partnership and an Islamic corporate governance system will be motivated by the need to avoid potentially harmful speculative effects and shareholder short-termism. Thus, there will be a more prominent role accorded to block shareholders in firms financing strategies than in western-orientated financial systems. Shared social and religious values are likely to restrict the potential locations for cross listing to regional exchanges with sizeable shari'ya compliant Islamic financial instrument markets and with investors who have similar beliefs.

\section{CONCLUSIONS}

This paper addresses the important questions regarding the ability of a fully shari'ya compliant stock exchange within an Islamic financial system to provide an effective source of development capital. This paper assesses the impact of the Khartoum stock exchange on the Sudan economy and reviews 
the financing options available for larger firms within the fully shari'ya compliant Sudanese financial system using the Sudan telecommunications company as a case study.

There are a number of difficulties in a study of this sort. Firstly, there is little empirical work on the impact of stock exchange financing within a fully shari'ya compliant Islamic financial system in a developing context. Then there are the conceptual problems that results from the differing interpretations and understandings of Qu'ran and canonical texts by the various schools of Islamic jurisprudence. This is a potential source of conflict in forming a policy response to the rapidly evolving area of commercial innovation within stock exchange finance. A major issue is the existence of strong-informational efficiency that follows from Islamic requirements for full disclosure of all publicly and privately available information, which contradicts finance theory in the west, although while this is based on common shared Islamic behavioural values and ethics the frequent lack of coherent regulation and appropriate enforcement mechanisms in developing countries infers that this assumption is at best tenuous. This is not simply a problem in the application of financial models but also in practice, as small family owned firms seek to retain sensitive information or would find the costly compliance of auditing and accounting measures to be prohibitive.

With respect to economic development problems arise due to the limited range of Islamic finance products that are easily traded and compatible with stock exchange operations. While there is evidence of positive corporate governance and monitoring as a result of mudarabah partnership-based instruments in contrast to debt contracts commonly associated with western financial markets, these contracts are perceived as risky, which deters investors. Therefore, current the partnership aspects in an Islamic financial system and the post-transaction monitoring costs arising from shari'ya compliance favours the relationship-based banking system and developing Islamic countries will continue to have a minimal stock markets emphasist. Larger firms such as the Sudan Telecommunications company that can cross list on regional exchanges benefit from substantial reductions in costs of equity capital. 


\section{REFERENCES}

Ali, A. A. 1999. 'Islamic Law', Chapter 2 in Islamic Banking, July 2001. Ed: Lewis, M. K. and Algaoud, L. M., Edward Elgar Publications: Cheltenham

Ali, A. A. 2007. 'Khartoum stock exchange: who should oversee its operations?' The Sudan Tribune, Khartoum: Sudan, Monday 25 June 2007

Abdouli, A. H. 1991. 'Access to Finance and Collaterals: Islamic Versus Western Banking.' Journal of King Abdulaziz University: Islamic Economics 3(1): 55-62

Aggarwal, R.K. \& Yousef, T. 2000. 'Islamic banks and investment financing.' Journal of Money, Credit and Banking 32(1): 93-120

Al-Suweilem, S. 1998. 'Venture Capital: A Potential Model of Musharaka.' Journal of King Abdulaziz University: Islamic Economics, 10: 3-20

Al Zawya 2009. Al Zawya business database. http://www.zawya.com/default.cfm?cc Accessed 2 August 2009

Asad, Z. 2008. 'Islamic Economics: A Survey of the Literature.' Munich Personal RePEc Archive, MPRE Paper No. 11024

Asutey, M. 2007. 'A Political economy Approach to Islamic Economics: Systemic Understanding for an alternative Economic System.' Kyoto Bulletin of Islamic Area Studies, 1(2): 3-18

Badr-El-Din, A. I. 2003. 'Poverty Alleviation via Islamic Banking Finance to Micro-Enterprises (MEs) in Sudan: Some Lessons for poor countries.' Universität Bremen, Institute for World Economics and International Management (IWIM), Sudan Economy Research Group, Discussion Paper No. 35

Brealey, R.A., Myers, S.C., \& Allen, F. 2008. 'Principles of corporate finance.' Ninth Edition. New York: McGraw Hill International.

Chapra, M. U. 1993. 'What is Islamic Economics.' Islamic Development Bank, Saudi Arabia, Islamic Research and Training Institute, IDB Prize Winners Lecture Series No.9

El-Din, S. \& El-Din, T. 2002. 'Towards an Islamic model of stock market.' Journal of King Abdulaziz University: Islamic Economics, 3(1): 57-81 
El-Din, S. T. 1996. 'The Stock-Exchange from an Islamic Perspective.' Journal of King Abdulaziz University: Islamic Economics, 8: 29-48

Eljelly, A. M. A. \& Abuldris, A. M. 2001. 'A Survey of Capital budgeting Techniques in the Public and Private Sectors of a Less Developed Country (LDC): The Case of the Sudan.' Journal of African Business, 2(1): 75-93

Fama, E. 1970. 'Efficient capital markets: a review of theory and empirical work.' The Journal of Finance, 25(2): 383-417.

Gordon, M.J. \& Shapiro, E. 1956. 'Capital equipment analysis: the required rate of profit.' Management Science, 3, 102-110.

Harvey, C. R. 1994. Conditional Asset Allocation in Emerging Markets, Working Paper: March 1994, Duke University, Durham, NC.

Hofstede, G. 1994. 'Cultural Constraints in Management Theories', International Review of Strategic Management, 5: 27-48

Iqbal, Z. 1997. 'Islamic financial systems.' Finance \& Development, (June): 42-45.

Kahf, M. 2003. 'Islamic Economics: Notes on Definition and Methodology.' Review of Islamic Economics, 13, 23-47

Kamali, M. H. 2007. ‘A Sahari'ah Analysis of Issues in Islamic Leasing.' Journal of King Abdulaziz University: Islamic Economics, 20(1): 3-21

Khan, T. \& BenDjilali, B. 2003. 'Modelling an Exit Strategy for Islamic Venture Capital Finance.' International Journal of Islamic Financial Services, 4(2): 1-10

Kuran, T. 1986. 'The economic system in contemporary Islamic thought: interpretation and assessment.' International Journal of Middle East Studies, 18(2): 135-164

Kuran, T. 1995. 'Islamic Economics and the Islamic Subeconomy.' Journal of Economic Perspectives, 9(4): $155-173$

Kuran, T. 2004. 'Why the Middle East is economically underdeveloped: historical mechanisms of institutional stagnation.' Journal of Economic Perspectives, 18(3): 71-90.

KSE Annual Report 2004. 'Khartoum Stock Exchange Annual Report 2004.' Khartoum, Sudan: Khartoum Stock Exchange (Arabic/ English). 
KSE website 2007. 'Khartoum Stock Exchange website (Arabic)', http://www.khartoumstock.com, Accessed 2 July 2007

Lewis, M.K. \& Algaoud, L.M. 2001. Islamic Banking. Cheltenham: Edward Elgar.

La Porta, R., Lopez-de-Silanes, F. \& Shleifer, A. 2008. 'The Economic Consequences of Legal Origins,' Journal of Economic Literature, 46: 285-332

Lintner, J. 1965. 'The valuation of risky assets and the selection of risky investments in stock portfolios and capital budgets.' Review of Economics and Statistics, 47(1): 13-37.

Mannan, M.A. 1993. 'Understanding Islamic finance: a study of the securities market framework.' Islamic Development Bank, Saudi Arabia, Islamic Research and Training Institute, Research paper no.18.

Markowitz, H. 1959. Portfolio selection: efficient diversification of investments. London: Chapman and Hall.

Metwally, M. M. 1984. 'The Role of the Stock Exchange in An Islamic Economy.' Journal of Research in Islamic Economics, 2(1): 19-28

Naughton, T. \& Naughton. S. 2000. 'Religion, ethics and stock trading: the case of an Islamic equities market.' Journal of Business Ethics, 23(2): 145-159

Obaidullah, M. 2006. 'Teaching Corporate Finance from an Islamic Perspective.' King Abdulaziz University Islamic Economics Research Centre, Kingdom of Saudi Arabia

Onour, I.A. 2002. 'Testing efficiency performance of Khartoum Stock Exchange.' University of Khartoum, Sudan, School of Management Studies, Research Paper.

Presley, J. R. \& Sessions, J. G. 1994. 'Islamic Economics: The Emergence of a New Paradigm.' The Economic Journal, 104(424): 584-596

Pryor, F. L. 2007. 'The Economic Impact of Islam on Developing Countries.' World Development, 35(11): 1815-1835

Rock, K. 1986. 'Why New Issues are Underpriced.' Journal of Financial Economics, 15, 187-212

Rowey, K., July, C., \& Fevre, M. 2006. 'Islamic finance: basic principles and structures.' Freshfield Bruckhaus Deringer, London. UK 
Rural Poverty 2008. 'Rural Poverty in Sudan.', http://www.ruralpovertyportal.org, Accessed 2 July 2008

Sharpe, W.F. 1964. 'Capital asset prices: a theory of market equilibrium under conditions of risk.' The Journal of Finance, 19(3): 425-442.

Siddiqi, M. N. 2005. 'Teaching Islamic Economics.' King Abdulaziz University Islamic Economics Research Centre, Kingdom of Saudi Arabia

Tignor, R. L. 1987. 'The Sudanese Private Sector: An Historical Overview.' The Journal of Modern African Studies, 25(2): 179-212

UN Sudan Millennium Goals 2004. 'Sudan Millennium Development Goals Interim Unified Report.' United Nations: New York 
Table 1. Trading Statistics on Selected Middle East and North Africa Stock Exchanges-2005

\begin{tabular}{|c|c|c|c|c|}
\hline Market & Established & $\begin{array}{c}\text { Market } \\
\text { capitalisation } \\
\text { (current US\$ mil) }\end{array}$ & $\begin{array}{c}\text { Market } \\
\text { capitalisation as } \\
\% \text { of GDP }\end{array}$ & $\begin{array}{c}\text { Stocks traded, } \\
\text { turnover ratio } \\
(\%)\end{array}$ \\
\hline \multicolumn{5}{|c|}{ Panel 1: Individual Country statistics } \\
\hline Saudi Stock Market & 2002 & $157,306.44$ & 73.35 & 10.08 \\
\hline Kuwait Stock Exchange & 1962 & $59,528.01$ & 142.58 & 10.55 \\
\hline Abu Dhabi Securities Market & 2000 & $30,362.51$ & 37.85 & 0.46 \\
\hline Egypt (Alexandria/ Cairo) & $1888 / 1903$ & $27,847.48$ & 39.26 & 1.81 \\
\hline Doha Securities Market & 1997 & $26,702.11$ & 130.73 & 1.36 \\
\hline Dubai Financial Market & 2000 & $14,284.23$ & 17.81 & 1.95 \\
\hline Bourse de Casablanca & 1929 & $13,050.18$ & 29.48 & 4.31 \\
\hline Amman Stock Exchange & 1999 & $10,962.98$ & 110.19 & 3.55 \\
\hline Bahrain Stock Exchange & 1989 & $9,701.77$ & 100.99 & 0.27 \\
\hline Muscat Securities Market & 1988 & $7,246.23$ & 33.56 & 1.49 \\
\hline Iraq Stock Exchange & 2004 & $2,686.94$ & 3.06 & 0.48 \\
\hline Bourse de Tunis & 1969 & $2,439.55$ & 9.07 & 1.03 \\
\hline *Khartoum Stock Exchange & 1995 & 746.56 & 3.92 & 1.31 \\
\hline Algeria Stock Exchange & 2003 & 143.64 & 0.22 & 0.01 \\
\hline Beirut Stock Exchange & 1920 & 0.99 & 0.01 & 0.60 \\
\hline \multicolumn{5}{|l|}{ Panel 2: Regional statistics } \\
\hline Middle East and North Africa & $100.00 \%$ & $363,009.62$ & & \\
\hline Gulf Region (incl. Saudi Arabia) & $84.06 \%$ & $305,131.30$ & & \\
\hline Saudi Arabia & $43.33 \%$ & $157,306.44$ & & \\
\hline $\begin{array}{l}\text { North Africa } \\
\text { (Algeria, Egypt, Morocco, } \\
\text { Tunisia) }\end{array}$ & $11.98 \%$ & $43,481.24$ & & \\
\hline Khartoum Stock Exchange & $0.21 \%$ & 746.56 & & \\
\hline
\end{tabular}

Source: Compiled by authors from national stock exchange websites and Arab Monetary Fund.

Notes (1) The Khartoum stock exchange is highlighted with an asterisk.

(2) Data on Iraq is collected direct from exchange website.

(3) Although the Saudi stock market had existed in an informal capacity since early 1990's the Tadawul stock exchange was only established in 2007 
Table 2: Descriptive Statistics - the Sudan Stock Exchange (US\$m), 1995-2006

\begin{tabular}{|c|c|c|c|c|c|c|c|c|c|c|c|c|}
\hline $\begin{array}{l}\text { DATA } \\
\text { PRIMARY MARKET }\end{array}$ & 1995 & 1996 & 1997 & 1998 & 1999 & 2000 & 2001 & 2002 & 2003 & 2004 & 2005 & 2006 \\
\hline Funds raised & 65.16 & 5.27 & 2.06 & 13.75 & 23.52 & 38.29 & 30.15 & 157.85 & 62.97 & 109.06 & & \\
\hline $\begin{array}{l}\text { Funds raised from Rights } \\
\text { and Bonus Issues }\end{array}$ & 1.15 & 2.09 & 0.28 & 6.09 & 22.17 & 34.24 & 29.99 & 56.61 & 60.43 & 3.98 & & \\
\hline \multicolumn{13}{|l|}{ SECONDARY MARKET } \\
\hline Listed companies & 34 & 40 & 41 & 42 & 43 & 44 & 44 & 46 & 47 & 48 & 49 & 51 \\
\hline Shares traded (m) & 115.73 & 24.91 & 164.82 & 11.67 & 198.57 & 14.17 & $8,768.89$ & $4,060.24$ & $9,745.46$ & $2,185.99$ & 142.88 & $5,032.22$ \\
\hline Market cap. & 44 & 32 & 139 & 111 & 237 & 392 & 457 & 593 & 741.22 & $2,058.42$ & $3,241.64$ & $3,563.49$ \\
\hline Value traded & 3.50 & 0.68 & 3.33 & 1.00 & 6.20 & 23.01 & 64.02 & 95.00 & 93.76 & 178.04 & 24.51 & 51.46 \\
\hline \multicolumn{13}{|c|}{ OTC MARKET TRANSACTIONS } \\
\hline Number of shares (m) & 0.49 & 2.06 & 2.33 & 3.39 & 3.99 & 3.58 & 226.96 & 351.36 & 167.25 & 791.92 & & \\
\hline Overseas & & & & & & 0.000 & 0.748 & 0.517 & 3.301 & 0.372 & & \\
\hline Inter-Family & 0.001 & 0.003 & 0.020 & 0.064 & 0.246 & 0.476 & 6.908 & 0.339 & 0.468 & 3.479 & & \\
\hline Inheritance & 0.002 & 0.004 & 0.002 & 0.005 & 0.041 & 0.142 & 0.102 & 0.203 & 0.139 & 7.426 & & \\
\hline Total & 0.003 & 0.007 & 0.023 & 0.069 & 0.287 & 0.618 & 7.758 & 1.059 & 4.047 & 3.926 & & \\
\hline \multicolumn{13}{|l|}{ RATIOS (\%) } \\
\hline Market cap./GDP & $0.60 \%$ & $0.35 \%$ & $1.19 \%$ & $1.32 \%$ & $2.22 \%$ & $3.40 \%$ & $3.56 \%$ & $4.02 \%$ & $4.34 \%$ & $6.96 \%$ & $12.01 \%$ & $10.48 \%$ \\
\hline $\begin{array}{l}\text { Market cap./money + } \\
\text { quasi-money }\end{array}$ & $0.00 \%$ & $0.01 \%$ & $0.02 \%$ & $0.08 \%$ & $0.03 \%$ & $0.04 \%$ & $0.47 \%$ & $0.05 \%$ & $0.14 \%$ & $10.28 \%$ & $38.46 \%$ & $45.95 \%$ \\
\hline Traded val./Market cap. & $7.98 \%$ & $2.14 \%$ & $2.39 \%$ & $0.90 \%$ & $2.86 \%$ & $5.86 \%$ & $14.01 \%$ & $15.97 \%$ & $12.65 \%$ & $12.13 \%$ & $0.75 \%$ & $1.44 \%$ \\
\hline OTC/Secondary Mkt. & $0.42 \%$ & $8.29 \%$ & $1.41 \%$ & $29.00 \%$ & $2.01 \%$ & $25.29 \%$ & $2.59 \%$ & $8.65 \%$ & $1.72 \%$ & $36.23 \%$ & & \\
\hline Savings rate/GDP & $6.72 \%$ & $2.99 \%$ & $3.02 \%$ & $2.66 \%$ & $3.07 \%$ & $3.42 \%$ & $4.45 \%$ & $5.23 \%$ & $5.87 \%$ & $6.68 \%$ & $11.44 \%$ & $9.70 \%$ \\
\hline $\begin{array}{l}\text { Life Expectancy at Birth } \\
\text { (Yrs) }\end{array}$ & 55.12 & 55.12 & 56.20 & 56.20 & 56.60 & 56.55 & 56.94 & 57.33 & 57.73 & 58.54 & 58.54 & 58.92 \\
\hline Literacy Rate & $46.10 \%$ & $46.10 \%$ & $53.30 \%$ & $53.30 \%$ & $50.00 \%$ & $34.60 \%$ & $34.60 \%$ & $34.60 \%$ & $50.50 \%$ & $50.50 \%$ & $50.50 \%$ & $50.50 \%$ \\
\hline
\end{tabular}

Source: Compiled by the authors from the Arab Monetary Fund, Bank of Sudan Annual Reports, and the Khartoum Stock Exchange website.

Notes: (1) Values for 2005, 2006 obtained from Al Zawya database (Dubai). 
Table 3. Sudan Licensed Broker Capitalization (US\$ ‘000) - 2004

\begin{tabular}{lcc}
\hline Broker & Capitalization (US\$ '000) & Market share (\%) \\
Financial Investment Bank (Public Company) & $3,976.62$ & 85.54 \\
Al-Ruad for Financial Services (Public Company) & 139.18 & 2.99 \\
Al-Muhajir for Financial & 119.29 & 2.57 \\
The National Company for Financial Transactions & 39.77 & 0.86 \\
Tarweeg Financial Investment Company Limited & 39.77 & 0.85 \\
Remaining Brokers (16) & 334.04 & 7.19 \\
Total & & $\mathbf{1 0 0 . 0 0}$ \\
\hline
\end{tabular}

Source: Compiled by authors from Khartoum stock exchange annual report (Arabic), 2004.

Note: (1) Remaining Brokers are: Green Gold for Securities, Elkashdeep for Securities, Securities Services Company Limited, Success Dealing Company Limited, Al-Araaf for Securities \& Investment, International Company for Monetary Management, Al-Amin for Securities, Branto for Financial Servcies, Al-Mustashar for Securities, Eldarhim Financial Investment Company, Al Tardamon for Fianncial Services, Al Baraka for Financial Services, Al Mansour Financial Services, Crawn for Financial Investment, Daw G for Financial Company, Gunoser Financial Investment Company. 
Table 4. Khartoum Stock Exchange listed firms, 2004

\begin{tabular}{|c|c|c|c|c|c|c|c|}
\hline Market & Company & $\begin{array}{c}\text { Listing } \\
\text { Date }\end{array}$ & $\begin{array}{c}\text { Days } \\
\text { Traded }\end{array}$ & $\begin{array}{c}\text { Value Traded (US\$ } \\
\text { Millions) }\end{array}$ & $\begin{array}{c}\text { Cumulative } \\
\text { proportion of } \\
\text { traded value }(\%)\end{array}$ & $\begin{array}{c}\text { Market } \\
\text { Capitalization (US\$ } \\
\text { Millions) }\end{array}$ & $\begin{array}{c}\text { Proportion of total } \\
\text { Market } \\
\text { Capitalization (\%) }\end{array}$ \\
\hline \multirow[t]{6}{*}{ Organized } & Sudatel (Sudan Telecom. Co. Ltd.) & 1997 & 224 & $97,165,303.27$ & 83.52 & $946,482,920.83$ & 62.66 \\
\hline & Nile Cement Company & 1996 & 11 & $15,485,218.38$ & 96.83 & $2,819,637.43$ & 0.19 \\
\hline & Sudanese French Bank & 1994 & 15 & $1,125,597.85$ & 97.79 & $11,815,371.00$ & 0.78 \\
\hline & Saudi Sudanese Bank & 1994 & 15 & $935,873.13$ & 98.59 & $11,455,775.40$ & 0.76 \\
\hline & Sudanese Islamic Bank & 1994 & 56 & $564,886.61$ & 99.09 & $7,571,693.82$ & 0.50 \\
\hline & Gum Arabic Company & 1994 & 79 & $548,757.26$ & 99.56 & $8,662,560.84$ & 0.57 \\
\hline Organized & Total (22 listed organized market firms): & -- -- & ---- & $116,338,538.66$ & $\mathbf{1 0 0 . 0 0}$ & & ---- \\
\hline \multirow{3}{*}{ Parallel } & Sudanese Free Zones \& Markets & 2002 & 44 & $15,066,434.34$ & 97.91 & $381,620,073.97$ & 25.26 \\
\hline & Al Rowad Financial Services Co. Ltd. & 2002 & 3 & $174,324.97$ & 99.04 & $38,970.85$ & 0.002 \\
\hline & Multi Media Company Limited & 2001 & 2 & $135,204.99$ & 99.91 & $254,384.22$ & 0.17 \\
\hline Parallel & Total (29 listed parallel firms): & ---- & ---- & $15,388,306.50$ & $\mathbf{1 0 0 . 0 0}$ & & ---- \\
\hline Total & Parallel and Organised (51 listed companies) & ---- & --- & & --- & $1,510,614,998.55$ & $\mathbf{1 0 0 . 0 0}$ \\
\hline \multirow[t]{3}{*}{ Funds } & Second Sudatel Dollar Fund & --- & 23 & $1,030,489.72$ & 93.66 & --- & --- \\
\hline & Development Fund & --- & 5 & $47,743.67$ & 97.99 & --- & ---- \\
\hline & Nile Fund & --- & 3 & $18,668.36$ & 99.69 & ---- & --- \\
\hline Funds & Total (7 listed funds): & ---- & ---- & $1,100,302.00$ & $\mathbf{1 0 0 . 0 0}$ & ---- & ---- \\
\hline \multirow[t]{5}{*}{ Shihama } & SHIHAMA $1 \backslash 4 \backslash 2003$ Annual 200,000 & --- & 35 & $6,635,379.18$ & 14.68 & ---- & --- \\
\hline & SHIHAMA $1 \backslash 7 \backslash 2004$ Annual 200,000 & --- & 10 & $5,504,598.16$ & 26.85 & --- & --- \\
\hline & SHIHAMA $1 \backslash 7 \backslash 2003$ Annual 200,000 & --- & 60 & $4,535,173.25$ & 36.88 & ---- & ---- \\
\hline & SHIHAMA $1 \backslash 10 \backslash 2003$ Annual 200,000 & --- & 13 & $4,023,473.97$ & 45.78 & ---- & --- \\
\hline & SHIHAMA $1 \backslash 1 \backslash 2004$ Annual 100,000 & --- & 58 & $3,552,160.17$ & 53.63 & ---- & --- \\
\hline Shihama & Total (34 listed Shihama certificates): & --- & ---- & $45,215,135.07$ & 100.00 & -- -- & -- -- \\
\hline--- & Organized Market Segment & --- & --- & $116,338,538.66$ & 65.34 & ---- & --- \\
\hline---- & Parallel Market Segment & ---- & ---- & $15,388,306.50$ & 8.64 & ---- & ---- \\
\hline--- & Funds Segment & --- & --- & $1,100,302.00$ & 0.62 & --- & --- \\
\hline--- & Shihama Market Segment & --- & --- & $45,215,135.07$ & 25.40 & --- & --- \\
\hline
\end{tabular}

Source: Khartoum Stock Exchange annual report (Arabic), 2004

Notes: (1) End of year Bank of Sudan SDD-US\$ exchange rate used 
Table 5. Khartoum Stock Exchange shareholding, 2009

\begin{tabular}{|c|c|c|c|c|c|c|c|c|}
\hline \multirow[t]{2}{*}{ Stock } & \multicolumn{2}{|c|}{ Government agencies } & \multicolumn{2}{|l|}{ Corporate } & \multicolumn{2}{|c|}{ Individual } & \multirow{2}{*}{$\begin{array}{c}\text { Blockholder } \\
\%\end{array}$} & \multirow{2}{*}{$\begin{array}{c}\text { Free Float } \\
\%\end{array}$} \\
\hline & Number & $\%$ & Number & $\%$ & Number & $\%$ & & \\
\hline Blue Nile Insurance Co. & 0 & 0.00 & 0 & 0.00 & 0 & 0.00 & 0.00 & 100.00 \\
\hline Blue Nile Mashreg Bank & 0 & 0.00 & 1 (Sudan) & 87.64 & 0 & 0.00 & 87.64 & 12.36 \\
\hline El Gharb Islamic Bank & 0 & 0.00 & $1(\mathrm{SA})$ & --- & 0 & 0.00 & --- & --- \\
\hline Sudan Tea Co. & 0 & 0.00 & 1 (Sudan) & --- & 0 & 0.00 & -- -- & -- -- \\
\hline Al Shamal Islamic Bank & 1 (Sudan) & -- -- & 5 (Sudan (4); SA) & ---- & 7 (Sudan (5); SA) & -- -- & ---- & -- -- \\
\hline Al Salam Bank & 0 & 0.00 & 5 (UAE (4); SA) & 35.50 & 2 (Sudan) & 16.97 & 52.47 & 47.53 \\
\hline Animal Resources Bank & 0 & 0.00 & 1 (Bahrain) & ---- & 0 & 0.00 & -- -- & -- -- \\
\hline Sudanese Ins. and Reins. Co. & 1 (Sudan) & ---- & 3 (Sudan) & ---- & 0 & 0.00 & ---- & ---- \\
\hline Tadamon Islamic Bank of Sudan & 1 (Sudan) & ---- & 3 (Sudan (2); KW) & 5.13 & 5 (Sudan (3); SA) & 44.68 & --- & ---- \\
\hline Sudanese Free Zones \& Mkts Co. & 0 & 0.00 & $>2(\mathrm{SA})$ & 49.00 & 0 & 0.00 & 41.00 & 59.00 \\
\hline Sudanese Kuwaiti Road Tpt Co. & 2 (KW; Sudan) & -- & $>2(\mathrm{KW}(>1) ;$ Sudan $(>1))$ & --- & 0 & 0.00 & -- -- & --- \\
\hline Juba Insurance Co. & 5 (Sudan) & 26.75 & 3 (Sudan) & 45.00 & 0 & 0.00 & 71.75 & 28.25 \\
\hline Nile Cement Co. & 1 (Sudan) & ---- & 3 (UAE; EGY; SA) & 82.97 & 0 & 0.00 & 82.97 & 17.03 \\
\hline Sudanese Islamic Bank & 0 & 0.00 & 2 (EGY; SA) & 5.00 & 0 & 0.00 & --- & --- \\
\hline Sudatel Telecom Group & 2 (Sudan; SA) & 26.18 & 1 (UAE) & 4.60 & 1 (LEB) & 4.00 & 35.80 & 64.20 \\
\hline Omdurman National Bank & 1 (Sudan) & 2.43 & 7 (Sudan (6); EGY) & 93.30 & 0 & 0.00 & 95.73 & 4.27 \\
\hline National Reinsurance Co. & 1 (Sudan) & 56 & 2 (Sudan) & 32.00 & 0 & 0.00 & 88.00 & 12.00 \\
\hline Sudan Oil seeds Co. & 1 (Sudan) & 58.00 & 0 & 0.00 & 0 & 0.00 & 58.00 & 32.00 \\
\hline Sudanese Animal Res. Co. & 0 & 0.00 & 1 (Sudan) & ---- & 0 & 0.00 & -- -- & -- -- \\
\hline Sudanese French Bank & 1 (Sudan) & 6.48 & 9 (Sudan (4); LUX; SW; USA; FR; LEB) & 56.58 & 3 (Sudan) & 14.55 & 95.06 & 4.94 \\
\hline Watania Cooperative Ins. Co. & 0 & 0.00 & 3 (Sudan) & ---- & 1 (Sudan) & -- -- & ---- & ---- \\
\hline Islamic Development Co. & 1 (Sudan) & ---- & 5 (Sudan (2); SA; EGY; Qatar ) & 45.46 & 0 & 0.00 & 45.46 & 54.54 \\
\hline Ivory Bank & 3 (Sudan) & 70.00 & 2 (Sudan) & 27.00 & --- & --- & 97.00 & 3.00 \\
\hline Export Development Bank & 1 (Sudan) & 21.85 & 2 (Sudan) & 42.79 & $>1$ (Sudan) & 34.91 & 99.55 & 0.45 \\
\hline Financial Investment Bank & 4 (Sudan (3); SA) & 70.00 & 6 (Sudan) & --- & 3 (Sudan (2); SA) & --- & --- & -- \\
\hline Gum Arabic Co. & 1 (Sudan) & -- -- & 5 (Sudan (4); UAE) & ---- & 0 & 0.00 & -- -- & -- -- \\
\hline General Insurance Co. & 0 & 0.00 & 0 & 0.00 & 1 (Sudan) & 60.00 & 60.00 & 40.00 \\
\hline Farmer's Commercial Bank & 1 (Bahrain) & --- & 2 (Sudan) & --- & 1 (Sudan) & --- & -- -- & --- \\
\hline Faisal Islamic Bank of Sudan & 0 & 0.00 & $1(\mathrm{EGY})$ & 25.00 & --- & ---- & 25.00 & 75.00 \\
\hline
\end{tabular}

Source: Compiled by authors from Al Zarwya database (Dubai)

Notes: (1) KW represents Kuwait, SA is Saudi Arabia, EGY is Egypt, UAE is United Arab Emirates, SW is Switzerland, USA is United States of America, FR is France,

LEB is Lebanon

(2) Data unavailable for 17 stocks (out of total of 46 listings): El Nilein Insurance Co., Commercial Bakeries Co., Assalama Ins., Gadarfi Investment Bank,

El Rowad Financial services Co., Foja International Ins. Co., Karmah Trading Co., White Nile Flour Mills, Multi-Media Co., Sudan Cinema Co., Al Hijra Exchange,

Workers National Bank, Saudi Sudanese Bank, National Petroleum Co., Tagseet Co., Al Mohager Int'l Investment, Al Rayaam Press and Publishing Co. 
Table 6: Bank Financing in Sudan, 1998-2006

\begin{tabular}{lccccccccc}
\hline $\begin{array}{l}\text { Mode of } \\
\text { financing }\end{array}$ & $\mathbf{1 9 9 8}$ & $\mathbf{1 9 9 9}$ & $\mathbf{2 0 0 0}$ & $\mathbf{2 0 0 1}$ & $\mathbf{2 0 0 2}$ & $\mathbf{2 0 0 3}$ & $\mathbf{2 0 0 4}$ & $\mathbf{2 0 0 5}$ & $\mathbf{2 0 0 6}$ \\
Murabaha & $54.37 \%$ & $49.12 \%$ & $33.74 \%$ & $39.53 \%$ & $35.92 \%$ & $44.64 \%$ & $38.52 \%$ & $43.29 \%$ & $53.37 \%$ \\
Musharaka & $21.11 \%$ & $30.80 \%$ & $42.88 \%$ & $30.97 \%$ & $27.88 \%$ & $23.22 \%$ & $31.99 \%$ & $30.82 \%$ & $20.38 \%$ \\
Murdaraba & $5.97 \%$ & $4.07 \%$ & $3.51 \%$ & $6.25 \%$ & $4.63 \%$ & $5.71 \%$ & $5.74 \%$ & $4.20 \%$ & $5.25 \%$ \\
Salam & $6.61 \%$ & $5.02 \%$ & $3.35 \%$ & $4.99 \%$ & $3.32 \%$ & $4.80 \%$ & $2.95 \%$ & $2.09 \%$ & $1.28 \%$ \\
$\quad$ Others* & $11.94 \%$ & $10.99 \%$ & $16.52 \%$ & $18.26 \%$ & $28.26 \%$ & $21.63 \%$ & $20.80 \%$ & $19.60 \%$ & $19.72 \%$ \\
& & & & & & & & $100 \%$ & $100 \%$ \\
Total (\%) & $100 \%$ & $100 \%$ & $100 \%$ & $100 \%$ & $100 \%$ & $100 \%$ & $100 \%$ & $100 \%$ \\
Total (US\$m) & 20.41 & 285.86 & 393.74 & 559.95 & 787.89 & $1,082.83$ & $1,706.25$ & $3,014.43$ & $4,861.51$ \\
\hline
\end{tabular}

Source: Compiled by the authors from the Bank of Sudan Annual Reports (1999-2006)

Note: (1) The 'others' mode of financing includes the ijara and mugawla modes

Table 7: Descriptive statistics and costs of equity for listed Sudatel stock, 2003-2007

\begin{tabular}{|c|c|c|c|c|c|}
\hline & 2003 & 2004 & 2005 & 2006 & 2007 \\
\hline \multicolumn{6}{|c|}{ Panel 1: Listing statistics } \\
\hline Khartoum & 589.08 & 946.48 & $1,743.01$ & $1,610.87$ & $1,551.18$ \\
\hline Bahrain & -- -- & -- -- & 131.25 & 130.36 & 130.36 \\
\hline Abu Dhabi & $1,123.30$ & $1,640.03$ & $2,653.04$ & $2,283.37$ & $2,388.76$ \\
\hline \multicolumn{6}{|c|}{ Traded Value (US\$m) } \\
\hline Khartoum & -- -- & 97.165 & -- -- & 126.16 & 131.45 \\
\hline Bahrain & ---- & --- & 0.00 & 0.00 & 0.00 \\
\hline Abu Dhabi & 20.31 & 165.84 & $1,106.21$ & 442.99 & 503.59 \\
\hline \multicolumn{6}{|c|}{ Turnover Ratio (\%) } \\
\hline Khartoum & -- -- & $10.26 \%$ & --- & $7.83 \%$ & $8.47 \%$ \\
\hline Bahrain & -- -- & -- -- & $0.00 \%$ & $0.00 \%$ & $0.00 \%$ \\
\hline Abu Dhabi & $1.81 \%$ & $10.11 \%$ & $41.70 \%$ & $19.40 \%$ & $21.08 \%$ \\
\hline \multicolumn{6}{|c|}{ Panel 2: Cost of Equity estimates } \\
\hline Khartoum & $24.89 \%$ & $29.15 \%$ & $26.46 \%$ & $55.33 \%$ & $13.07 \%$ \\
\hline Abu Dhabi & $24.89 \%$ & $9.18 \%$ & $9.00 \%$ & $50.07 \%$ & $13.36 \%$ \\
\hline
\end{tabular}

Source: Compiled by the authors from the Arab Monetary Fund, Khartoum, Bahrain and Abu Dhabi Stock Exchange websites

Notes: (1) The dividend capitalisation method assumes constant (mean) rate of growth rate of dividends of $6 \%$ 
Table 8. Descriptive statistics - monthly equity returns (Saudi Rials), April 2003 to December 2008.

\begin{tabular}{|c|c|c|c|c|c|c|c|c|c|}
\hline & $\begin{array}{c}\text { Sudatel } \\
\text { (Abu Dhabi) }\end{array}$ & $\begin{array}{c}\text { Sudatel } \\
\text { (Khartoum) }\end{array}$ & $\begin{array}{l}\text { S\&P Saudi } \\
\text { Arabia }\end{array}$ & S\&P Oman & S\&P Egypt & S\&P Bahrain & MSCI World & S\&P Kenya & S\&P Morocco \\
\hline \multicolumn{10}{|c|}{ Panel 1: Descriptive Statistics } \\
\hline Observations & 68 & 68 & 68 & 68 & 68 & 68 & 68 & 68 & 68 \\
\hline Mean & $1.82 \%$ & $2.29 \%$ & $2.60 \%$ & $3.25 \%$ & $5.12 \%$ & $2.34 \%$ & $1.36 \%$ & $3.26 \%$ & $3.52 \%$ \\
\hline Std. Dev. & $16.32 \%$ & $13.32 \%$ & $9.53 \%$ & $4.99 \%$ & $9.10 \%$ & $4.00 \%$ & $2.72 \%$ & $5.81 \%$ & $7.75 \%$ \\
\hline \multicolumn{10}{|l|}{ Panel 2: Correlations } \\
\hline Sudatel (Abu Dhabi) & $100.00 \%$ & & & & & & & & \\
\hline Sudatel (Khartoum) & $34.11 \%$ & $100.00 \%$ & & & & & & & \\
\hline S\&P Saudi Arabia & $-15.05 \%$ & $-2.76 \%$ & $100.00 \%$ & & & & & & \\
\hline S\&P Oman & $-27.68 \%$ & $-14.94 \%$ & $39.99 \%$ & $100.00 \%$ & & & & & \\
\hline S\&P Egypt & $-5.47 \%$ & $7.45 \%$ & $23.17 \%$ & $28.82 \%$ & $100.00 \%$ & & & & \\
\hline S\&P Bahrain & $-9.02 \%$ & $3.42 \%$ & $22.98 \%$ & $27.18 \%$ & $38.74 \%$ & $100.00 \%$ & & & \\
\hline MSCI World & $0.65 \%$ & $1.70 \%$ & $-2.09 \%$ & $4.05 \%$ & $11.28 \%$ & $-6.15 \%$ & $100.00 \%$ & & \\
\hline S\&P Kenya & $-15.22 \%$ & $5.30 \%$ & $7.14 \%$ & $25.30 \%$ & $13.65 \%$ & $2.44 \%$ & $35.91 \%$ & $100.00 \%$ & \\
\hline S\&P Morocco & $-12.57 \%$ & $6.98 \%$ & $-10.74 \%$ & $1.81 \%$ & $1.95 \%$ & $-4.18 \%$ & $31.81 \%$ & $0.62 \%$ & $100.00 \%$ \\
\hline
\end{tabular}

Source: Compiled by authors from Datastream.

Notes: (1) Data for Sudatel (Abu Dhabi and Khartoum listings) obtained from respective national securities exchanges.

(2) Sudatel Abu Dhabi and Khartoum market series constructed following Standard \& Poors index methods.

(3) All series translated into Saudi Rials to facilitate comparison across wider MENA region. 
Table 9: Portfolio characteristics for Sudatel Khartoum and Abu Dhabi listings

\begin{tabular}{|c|c|c|c|c|c|}
\hline & Mean & Max & Min & Std. Dev. & Risk-Return ratio \\
\hline \multicolumn{6}{|c|}{ Panel 1: Portfolio containing all markets and the following Sudatel listing } \\
\hline Abu Dhabi & $26.65 \%$ & $51.81 \%$ & $9.57 \%$ & $4.61 \%$ & $1.5289 *$ \\
\hline Khartoum & $25.31 \%$ & $52.34 \%$ & $6.81 \%$ & $5.12 \%$ & 1.3437 \\
\hline \multicolumn{6}{|c|}{ Panel 2: Portfolio with Sudatel (Khartoum) and the following } \\
\hline Morocco and Egypt & $49.66 \%$ & $77.74 \%$ & $21.54 \%$ & $14.82 \%$ & 0.8042 \\
\hline Egypt and Kenya & $51.04 \%$ & $110.47 \%$ & $14.43 \%$ & $14.71 \%$ & 0.7694 \\
\hline Saudi Arabia and Oman & $41.98 \%$ & $101.63 \%$ & $-11.94 \%$ & $12.22 \%$ & 0.8999* \\
\hline
\end{tabular}

Notes: (1) Annual geometric means of monthly arbitrage premiums evaluated in Saudi Rials and in basis points (2) All portfolio statistics are annualized. Risk-return ratio is the mean of the annualized mean divided by standard deviation

(3) * represent the best returns to risk portfolio performance

Figure 1. Khartoum stock exchange and Sudatel stock price indices and traded value (US\$m)

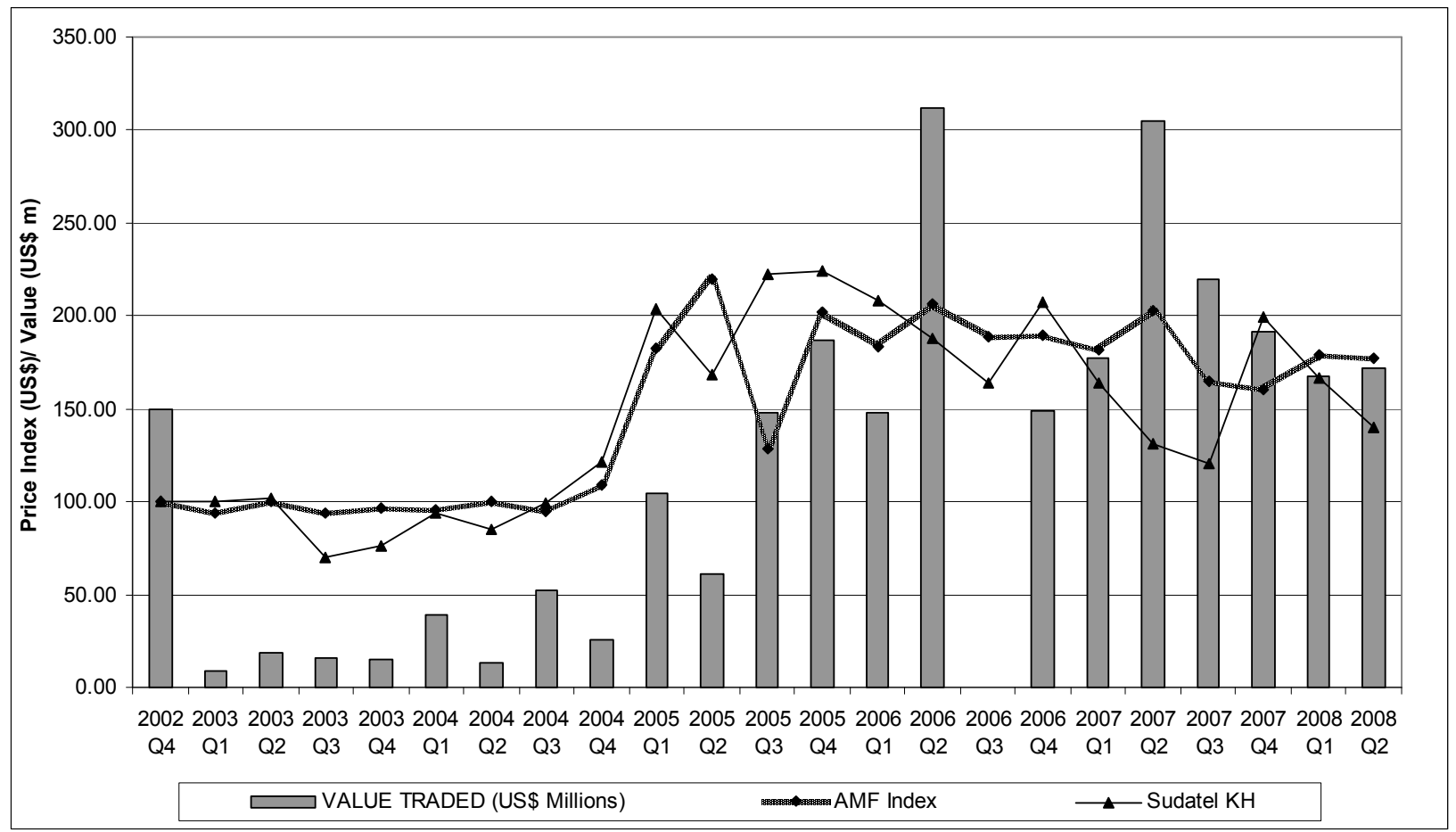

Source: Arab Monetary Fund (AMF) annual reports and KSE Annual Report 2004 (Arabic)

Notes: (1) Sudatel stock price index generated from stock price returns series assuming a base level of 100 in 2002Q4

(2) AMF (Khartoum) price index is generated using top 11 traded local stocks and is market capitalization weighted. It assumes a base of 100 in 2002Q4 